\title{
Analytical Hierarchy Process to Evaluate Supplier Performance in Timber Industry
}

\author{
Shelvy Kurniawan'; Bayu Septian Nugraha ${ }^{2}$; Prima Yolanda ${ }^{3}$ \\ ${ }^{1,2,3}$ Management Department, BINUS Business School Undergraduate Program, Bina Nusantara University \\ Jln. K. H. Syahdan No. 9, Jakarta Barat 11480, Indonesia \\ ${ }^{1}$ shelvy.kurniawan001@binus.ac.id; 2mrsidemen@gmail.com; 3primayolanda2807@gmail.com
}

Received: $30^{\text {th }}$ January 2018/ Revised: $7^{\text {th }}$ May 2018/ Accepted: $8^{\text {th }}$ May 2018

How to Cite: Kurniawan, S., Nugraha, B. S., \& Yolanda, P. (2018). Analytical Hierarchy Process to Evaluate Supplier

Performance in Timber Industry. Binus Business Review, 9(2), 133-143.

https://doi.org/10.21512/bbr.v9i2.4404

\begin{abstract}
This descriptive and cross - sectional research was conducted to determine the priority criteria in supplier selection and the best supplier for Timber Industry as the unit of analysis. Data were collected through interview and questionnaire with the operational Manager of the company. The analysis method used was Analytical Hierarchy Process (AHP) that could assist decision making with criteria, sub-criteria, and several alternatives that had been determined by the company. The researchers find that there are four criteria which become the consideration in selecting supplier those are price, product, service, and delivery. From the analysis, it is found that the company should prioritize price compared to other criteria in selecting the supplier. Meanwhile, the other criteria (product, delivery, and service) sequentially become the second, third, and fourth priority criteria in selecting the suppliers. The other result of this research is the company can find the order of the best suppliers which can be recommended to the company.
\end{abstract}

Keywords: Analytical Hierarchy Process (AHP), supplier performance, supplier selection

\section{INTRODUCTION}

Competitiveness is important for the companies to survive and grow. Competitiveness can be achieved by the company through various ways. One of them is by having a competitive advantage for the suppliers which can become the inputs in the supply chain of each company. This is supported by Heizer, Render, and Munson (2016). They said that supplier was one of the important factors in Supply Chain Management (SCM). It managed the activities ranging from acquiring raw materials, supporting the production to delivering the product to the consumers.

According to interviews with the operational manager, there is always a problem in the procurement of goods every year. It is because the suppliers cannot meet the needs of raw materials. The problems that often occur are related to unavailability of raw materials, quality of raw material, unstable price, and delivery from suppliers. From supplier problems that often occur, it is important for timber industry to choose which supplier is the best for the company. Because it is quite difficult to choose suppliers in accordance with the needs of the company, the company needs decision-making method which can facilitate various criteria and become the needs of the company.

There are various methods that can be used to help companies in making decisions regarding the supplier selection. There are Analytical Hierarchy Process (AHP) and ELimination Et Choix Traduisant la Realit $\tilde{A}$ (ELimination and Choice Expressing Reality)(ELECTRE). Moreover, Garoma and Diriba (2014) stated that Multiple-Criteria Decision Making (MCDM) was considered as one of the rapidly growing areas of operations research dedicated to the provision of mathematical and analytical tools or mechanism. It tackled complex problems involving multiple criteria, goals, or objectives of conflicting nature. One of the Decision Support System (DSS) techniques was AHP. It enabled users to solve a complex problem by reducing it into simple pairwise permutation and comparisons of criteria. 
According to Arama, Criste, Criste, and Panaite (2015), AHP is a structured method. It allows organizing and ranking complex decisions on the basis of mathematics and psychology. Rather than prescribing a correct decision, AHP helps the decision-makers to find a solution that fits their purpose and the manner of understanding the problem. Furthermore, Prasad and Kousalya (2017) explained that AHP was a method that helped in decision-making system by considering the factors, perceptions, preferences, experiences, and intuition. Then, Schmidt, Aumann, Hollander, Damm, and von der Schulenburg (2015) agreed AHP was one of the methods for MCDM. AHP disaggregated a complex decision problem into different hierarchical levels. The weight for each criterion and alternative were judged in pairwise comparisons and priorities.

Ajami and Ketabi (2012) also mentioned that AHP structured the decision problem in levels which corresponded to one's understands regarding the situation such as goals, criteria, sub-criteria, and alternatives. By breaking the problem into levels, the decision-maker could focus on smaller sets of decisions.

Besides AHP, there is the other method that can be used to analyze MCDM. It is ELECTRE. ELECTRE method is an MCDM based on the concept of outranking by using the pairwise comparison of alternatives in each appropriate criteria (Marlinda, 2016). Yücel and Görener (2016) also suggested that ELECTRE was MCDM with the concept of outranking. It was introduced by Bernard Roy in 1968.

From the research of Supraja and Kousalya (2016), and Yücel and Görener (2016), the researchers can compare the use of AHP and ELECTRE. AHP method performs consistency analysis by testing the consistent value of each input from each source. It is important to consider the input of each choice like human perception, and there may be the inconsistency of each given value. Meanwhile, ELECTRE method does not count the value of consistency. AHP method can analyze the alternative decision-making with predetermined criteria and sub-criteria and determine the weight of each output. ELECTRE method output only determines the rankings without the weight value. By considering the importance of this research which is to know the priority number with consistency analysis, the researchers will focus on using AHP.

Garoma and Diriba (2014) analyzed the development of supplier selection methodology for banking industry in Ethiopia. they addressed the supplier selection problem through application of AHP by using historical data from generator purchase in Awash International Bank (AIB). They indicated six commonly used factors for supplier evaluations which were extracted from several literatures. The factors were price, quality, delivery, financial position and after-sales service. The result indicated that quality/ technical had a higher rank (46\%), price/cost (25\%), after-sales service (11\%). Meanwhile, delivery, financial position, and reputation had equal importance and attribute of $6 \%$ each.
In this research, the researchers will focus on evaluating supplier's performance using AHP in different industry and different country. This research will focus in one of the company in Indonesia in timber industry. It is one of the existing companies in Indonesia. It is located at Depok, West Java. The products are a wooden pallet and haspel timber.

Besides researching in different industry and country, the differences of this research compared to several previous AHP's research are the use of competitive price and consistent price sub-criteria to explain about price, the use of availability of goods, consistent quality, the frequency of defective products sub-criteria to explain about product, the use of speed of response, after-sales-warranty, and flexibility subcriteria to explain about service, and the use of delivery time and delivery cost sub-criteria to explain about delivery. Those criteria are combining from literature search and based on interview with operational manager. Those criteria are summarized in Table 1.

Table 1 Supplier Selection Criteria in Timber Industry

\begin{tabular}{ll}
\hline Criteria & Definition \\
\hline Price & $\begin{array}{l}\text { Supplier's ability to offer competitive } \\
\text { prices to timber industry. }\end{array}$ \\
Product & $\begin{array}{l}\text { Supplier's ability to deliver products that } \\
\text { conform to product standards required by } \\
\text { timber industry. }\end{array}$ \\
Service & $\begin{array}{l}\text { Supplier's ability to serve and cooperate } \\
\text { with timber industry. }\end{array}$ \\
Delivery & $\begin{array}{l}\text { Supplier's ability to deliver goods to } \\
\text { timber industry. }\end{array}$ \\
\hline
\end{tabular}

(Source: Interview results, 2017)

Based on the research background, there are two objectives in this research. First, it determines the priority criteria in supplier selection of Timber Industry $(\mathrm{O} 1)$. Second, it determines the best supplier for Timber Industry in fulfilling raw material needs $(\mathrm{O} 2)$.

\section{METHODS}

This research is descriptive study. The unit of analysis is Timber Industry. The time horizon for this research is cross-sectional. According to Sekaran and Bougie (2013), a cross-sectional study can be done to collect data at a single point in time.

The researchers use both primary and secondary data. The secondary data is used to get literature review to support this research. It includes analyzing several previous researches to support this research. It is categorized as qualitative data. The primary data is used to answer the objectives of this research (O1 and $\mathrm{O} 2$ ). It consists of interview and questionnaire 
results answered by the operational manager. He has a responsibility in selecting and allocating order to suppliers. The data taken are categorized as qualitative data.

This research uses AHP method. According to Joshi, Lee, Melson, and Narra (2011), AHP is developed by Thomas Saaty to guide MCDM. It is one of the most widely used methods of analysis for decision making nowadays.

In analyzing the AHP method, there are several steps which the researchers have done. First, the researchers determine the criteria and sub-criteria. Second, the researchers determine the alternative. Third, the researchers collect data for alternatives. Fourth, the researchers prepare the item of the questionnaire. Fifth, the researchers do the interview process regarding the questionnaire that has been created. Sixth, the researchers review the interview result. Seventh, the researchers calculate the weights of criteria, sub-criteria, and alternatives. Eighth, the researchers test the consistency. Last, the researchers have problem analysis, conclusions, and suggestions.

\section{RESULTS AND DISCUSSIONS}

Based on interview results with the company, there are five suppliers as seen in Table 2.

Table 2 List of suppliers in Timber Industry

\begin{tabular}{cll}
\hline Supplier & Name & Location \\
\hline A & Cahaya Abadi Karya & Kelapa Nunggal \\
B & Awi Kayu & Pondok Rinjani \\
C & Mandiri Palet & Jonggol \\
D & Aming Wood & Purwakarta \\
E & Abdi Karya & Pondok Rajak \\
\hline
\end{tabular}

(Source: Timber Industry, 2017)

Besides the information about suppliers, to analyze supplier performance using AHP, the other needed information is the criteria which are used to evaluate the supplier performance. As explained in Table 1, the researchers also determine sub-criteria. It is used as an indicator by the company to assess the suppliers. The sub-criteria are described in Table 3 , and AHP criteria hierarchy structure for supplier selection is in Figure 1.

After making AHP criteria hierarchy structure, the next step is to develop a paired questionnaire of criteria and sub-criteria. Questionnaires are made with the aim of obtaining data that will be used for analysis in AHP methods. Questionnaires are made on a paired scale of criteria and sub-criteria. An example of paired comparison questionnaires for the criteria category is shown in Table 3.
Table 3 Criteria and Sub-Criteria for Supplier Selection in Timber Industry

\begin{tabular}{|c|c|c|}
\hline Criteria & Sub-Criteria & Indicators \\
\hline \multirow[t]{2}{*}{ Price } & $\begin{array}{l}\text { Competitive } \\
\text { price }\end{array}$ & $\begin{array}{l}\text { The given price is } \\
\text { competitive compared to } \\
\text { competitors. }\end{array}$ \\
\hline & $\begin{array}{l}\text { Consistent } \\
\text { price }\end{array}$ & $\begin{array}{l}\text { Consistent pricing and tend } \\
\text { not to change too often. }\end{array}$ \\
\hline \multirow{3}{*}{ Product } & $\begin{array}{l}\text { Availability of } \\
\text { goods }\end{array}$ & $\begin{array}{l}\text { Supplier's ability to provide } \\
\text { the needed goods at the right } \\
\text { time. }\end{array}$ \\
\hline & $\begin{array}{l}\text { Consistent } \\
\text { quality }\end{array}$ & $\begin{array}{l}\text { Product quality tends to be } \\
\text { consistent. }\end{array}$ \\
\hline & $\begin{array}{l}\text { The frequency } \\
\text { of defective } \\
\text { products }\end{array}$ & $\begin{array}{l}\text { The frequency of defective } \\
\text { products supplied by the } \\
\text { supplier. }\end{array}$ \\
\hline \multirow{3}{*}{ Service } & $\begin{array}{l}\text { Speed of } \\
\text { response }\end{array}$ & $\begin{array}{l}\text { Supplier's ability to provide } \\
\text { feedback when there are } \\
\text { reservations or complaints. }\end{array}$ \\
\hline & $\begin{array}{l}\text { After-sales } \\
\text { warranty }\end{array}$ & $\begin{array}{l}\text { Services provided after- } \\
\text { sales occurred such as } \\
\text { replacement of defective } \\
\text { items. }\end{array}$ \\
\hline & Flexibility & $\begin{array}{l}\text { Flexible services such as } \\
\text { change of delivery date, } \\
\text { change of the quantity of } \\
\text { goods, and any agreements } \\
\text { that may change depending } \\
\text { on the company's request. }\end{array}$ \\
\hline \multirow{2}{*}{ Delivery } & Delivery time & $\begin{array}{l}\text { Speed of supplier in } \\
\text { providing goods to be sent } \\
\text { to timber industry. }\end{array}$ \\
\hline & Delivery cost & $\begin{array}{l}\text { Shipping costs required by } \\
\text { the company to deliver the } \\
\text { goods. }\end{array}$ \\
\hline
\end{tabular}

From Table 4, the researchers can get the result of paired comparison. Meanwhile, the paired comparison rating scale which is used by the company to evaluate the paired questionnaire is explained in Table 5. From information in Table 5, the company can use it as reference in making scoring of paired comparison in Table 4. The result in Table 4 is obtained from the questionnaire which is filled by operational manager.

After the questionnaire is filled by the respondent as presented in Table 4, the next step is to input the data and transform it into paired comparison table to determine the weight of each comparison. Later, the weight can be used to determine which criteria or sub-criteria are more important or better than others. Paired comparison of Table 4 is presented in Table 6 . The data in Table 6 refer to the rating scale in Table 4 , where Table 4 shows that delivery has a scale of $1 / 2$ times more important than price and vice versa. Price has a scale of 2 times more important than delivery. 


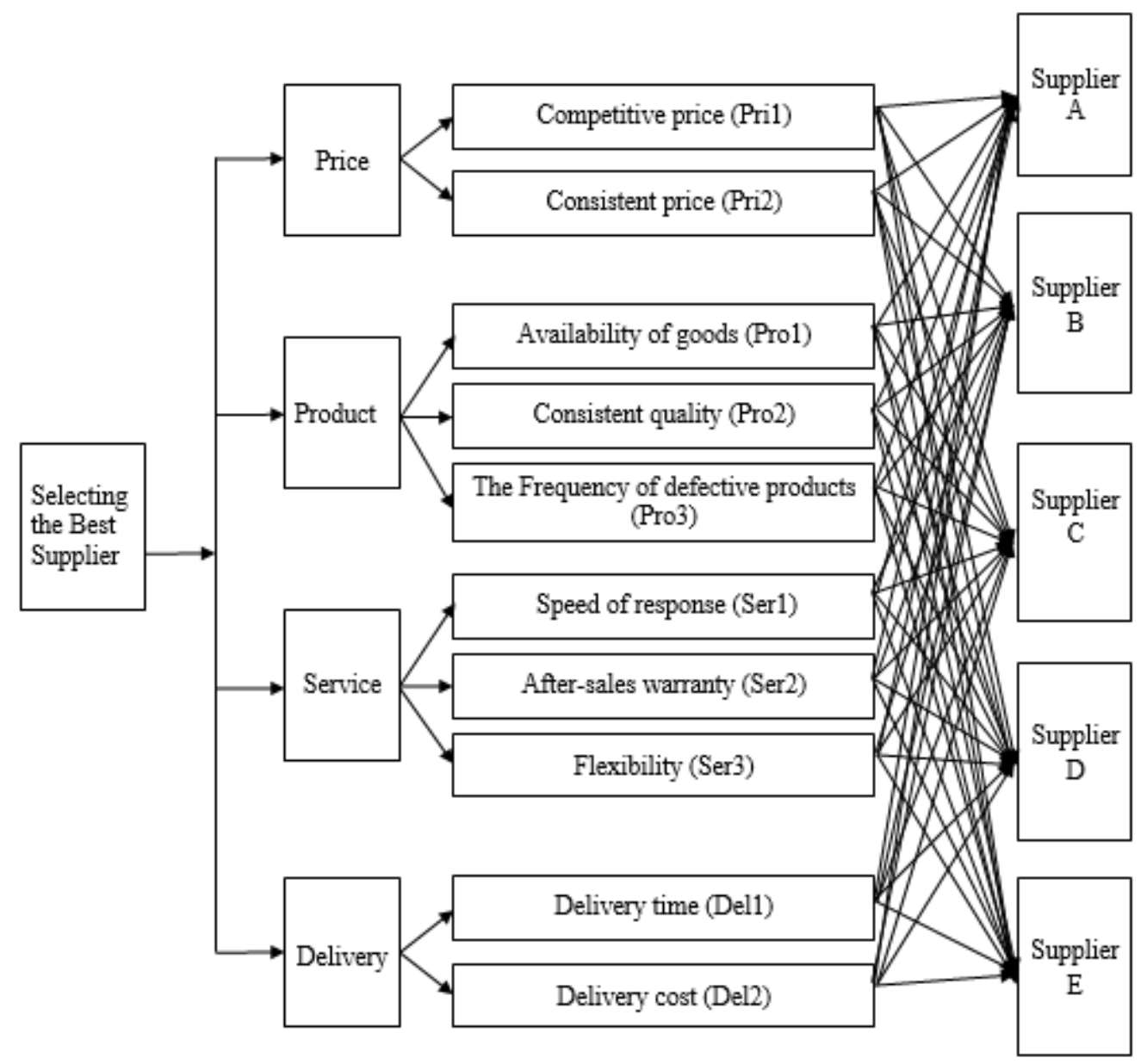

Figure 1 AHP Criteria Hierarchy Structure

(Source: The researchers, 2017)

Table 4 Paired Comparison Questionnaires for the Criteria

\begin{tabular}{|c|c|c|c|c|c|c|c|c|c|c|c|c|c|c|c|c|c|c|}
\hline KPI & 9 & 8 & 7 & 6 & 5 & 4 & 3 & 2 & 1 & 2 & 3 & 4 & 5 & 6 & 7 & 8 & 9 & KPI \\
\hline Price & & & & & & & & & $\sqrt{ }$ & & & & & & & & & Product \\
\hline Price & & & & & & & $\sqrt{ }$ & & & & & & & & & & & Service \\
\hline Price & & & & & & & & $\sqrt{ }$ & & & & & & & & & & Delivery \\
\hline Product & & & & & & & & $\sqrt{ }$ & & & & & & & & & & Service \\
\hline Product & & & & & & & & $\sqrt{ }$ & & & & & & & & & & Delivery \\
\hline Service & & & & & & & & & & & $\sqrt{ }$ & & & & & & & Delivery \\
\hline
\end{tabular}

(Source: Timber Industry, 2017)

Table 5 The Paired Comparison Rating Scale

\begin{tabular}{ll}
\hline Importance Level & Definition \\
\hline 1 & Both elements have an equally important level. \\
3 & One element is slightly more important than the other element. \\
5 & One element is more important than another element. \\
7 & One element is more important than other elements. \\
9 & One element is absolutely more important than the other element \\
$2,4,6,8$ & The value between two adjacent consideration values \\
Reverse & If element i has one of the above numbers compared to element $\mathrm{j}, \mathrm{j}$ has the opposite \\
& value compared to element $\mathrm{i}$. \\
\hline
\end{tabular}


Table 6 Paired Comparison Matrices Between Criteria

\begin{tabular}{lcccc}
\hline Criteria & Price & Product & Service & Delivery \\
\hline Price & 1 & 1 & 3 & $2 *$ \\
Product & 1 & 1 & 2 & 2 \\
Service & $1 / 3$ & $1 / 2$ & 1 & $1 / 3$ \\
Delivery & $1 / 2 *$ & $1 / 2$ & 3 & 1 \\
\hline Total & $25 / 6$ & 3 & 5 & $51 / 3$ \\
\hline
\end{tabular}

(Source: The researchers, 2017)

The next step is to create a paired comparison matrix for sub-criteria, which can be seen in Table 7 until Table 10. The steps to get paired comparison matrix for sub-criteria are the same with the steps to get comparison matrix for criteria (as presented in Table 4 to Table 6). First, the paired comparison questionnaires for each sub-criterion are filled by operational manager. After that, the result will be transformed into paired comparison in Table 7 to Table 10.

Table 7 Paired Comparison Matrices between Sub-Criteria of Price

\begin{tabular}{ccc}
\hline Price (Pri) & Pri1 & Pri2 \\
\hline Pri1 & 1 & 4 \\
Pri2 & $1 / 4$ & 1 \\
\hline Total & $11 / 4$ & 5 \\
\hline
\end{tabular}

(Source: The researchers, 2017)

Table 7 shows that competitive price (Pri1) has a scale of 4 times more important than consistent price (Pri2). Then, consistent price (Pri2) is $1 / 4$ times more important than competitive price (Pri1).

Then, Table 8 shows that availability of goods (Pro1) is 3 times more important than consistent quality (Pro2). Meanwhile, consistent quality (Pro2) has a scale of $1 / 3$ times more important than availability of goods (Pro1). Related to how to read the scoring between sub-criteria Pro1 and Pro2, the researchers read the scoring of the other sub-criteria of product which is presented in Table 8.

Table 8 Paired Comparison Matrices between Sub-Criteria of Product

\begin{tabular}{cccc}
\hline Product (Pro) & Pro1 & Pro2 & Pro3 \\
\hline Pro1 & 1 & 3 & 2 \\
Pro2 & $1 / 3$ & 1 & $1 / 3$ \\
Pro3 & $1 / 2$ & 3 & 1 \\
\hline Total & $15 / 6$ & 7 & $31 / 3$ \\
\hline
\end{tabular}

(Source: The researchers, 2017)
Table 9 Paired Comparison Matrices between Sub-Criteria of Service

\begin{tabular}{cccc}
\hline Service (Ser) & Ser1 & Ser2 & Ser3 \\
\hline Ser1 & 1 & $1 / 5$ & $1 / 3$ \\
Ser2 & 5 & 1 & 3 \\
Ser3 & 3 & $1 / 3$ & 1 \\
\hline Total & 9 & $11 / 2$ & $41 / 3$ \\
\hline
\end{tabular}

(Source: The researchers, 2017)

Table 9 explains that speed of response (Ser1) is $1 / 5$ times more important than after-sales warranty (Ser2). Moreover,after-sales warranty (Ser2) has a scale of 5 times more important than speed of response (Ser1). It is same related to how to read the scoring between sub-criteria Ser1 and Ser2. It can be used to read the scoring of the other sub-criteria of service which is presented in Table 9.

Table 10 Paired Comparison Matrices between Sub-Criteria of Delivery

\begin{tabular}{ccc}
\hline Delivery (Del) & Del1 & Del2 \\
\hline Del1 & 1 & $1 / 5$ \\
Del2 & 5 & 1 \\
\hline Total & 6 & $11 / 5$ \\
\hline
\end{tabular}

(Source: The researchers, 2017)

Table 10 shows that delivery time (Del1) has a scale of $1 / 5$ times more important than delivery cost (Del2). However, delivery cost (Del2) is 5 times more important than delivery time (Del1).

After finishing the paired comparison matrix for each criterion and sub-criterion, the researchers make a comparison among the five suppliers based on each sub-criterion. The assessments of the five suppliers based on predetermined sub-criteria are described in Table 11 to Table 20.

The way to read the result is the same from Table 11 to Table 20. For the explanation, the researchers use Supplier A and Supplier B as the example. From the result in Table 11, it can be analyzed that in subcriteria of competitive price, Supplier A is $1 / 3$ times better than Supplier B. However, Supplier B is 3 times better than Supplier A.

In Table 12, it can be analyzed that for subcriteria of consistent price, Supplier A is $1 / 2$ times better than Supplier B. Then, Supplier B is 2 times better than Supplier A. Similarly, in Table 13, Supplier A is 5 times better than Supplier B in availability of goods. However, Supplier B is $1 / 5$ times better than Supplier A in this criterion. 
Table 11 Paired Comparison Matrices among Suppliers based on Sub-Criteria of Competitive Price

\begin{tabular}{cccccc}
\hline Pri1 & A & B & C & D & E \\
\hline Supplier A & 1 & $1 / 3$ & 1 & 3 & 3 \\
Supplier B & 3 & 1 & 3 & 3 & 2 \\
Supplier C & 1 & $1 / 3$ & 1 & 3 & 3 \\
Supplier D & $1 / 3$ & $1 / 3$ & $1 / 3$ & 1 & $1 / 2$ \\
Supplier E & $1 / 3$ & $1 / 2$ & $1 / 3$ & 2 & 1 \\
\hline Total & $52 / 3$ & $21 / 2$ & $52 / 3$ & 12 & $91 / 2$ \\
\hline
\end{tabular}

(Source: The researchers, 2017)

Table 12 Paired Comparison Matrices among Suppliers based on Sub-Criteria of Consistent Price

\begin{tabular}{cccccc}
\hline Pri2 & A & B & C & D & E \\
\hline Supplier A & 1 & $1 / 2$ & 2 & 3 & 2 \\
Supplier B & 2 & 1 & 4 & 5 & 3 \\
Supplier C & $1 / 2$ & $1 / 4$ & 1 & 3 & 1 \\
Supplier D & $1 / 3$ & $1 / 5$ & $1 / 3$ & 1 & $1 / 2$ \\
Supplier E & $1 / 2$ & $1 / 3$ & 1 & 2 & 1 \\
\hline Total & $41 / 3$ & $22 / 7$ & $81 / 3$ & 14 & $71 / 2$ \\
\hline
\end{tabular}

(Source: The researchers, 2017)

Table 13 Paired Comparison Matrices among Suppliers based on Sub-Criteria of Availability of Goods

\begin{tabular}{cccccc}
\hline Pro1 & A & B & C & D & E \\
\hline Supplier A & 1 & 5 & 3 & 3 & 6 \\
Supplier B & $1 / 5$ & 1 & $1 / 2$ & $1 / 3$ & 1 \\
Supplier C & $1 / 3$ & 2 & 1 & $1 / 2$ & 4 \\
Supplier D & $1 / 3$ & 3 & 2 & 1 & 5 \\
Supplier E & $1 / 6$ & 1 & $1 / 4$ & $1 / 5$ & 1 \\
\hline Total & 2 & 12 & $63 / 4$ & 5 & 17 \\
\hline
\end{tabular}

(Source: The researchers, 2017)

Table 14 Paired Comparison Matrices among Suppliers based on Sub-Criteria of Consistent Quality

\begin{tabular}{cccccc}
\hline Pro2 & A & B & C & D & E \\
\hline Supplier A & 1 & 3 & 2 & 2 & 4 \\
Supplier B & $1 / 3$ & 1 & $1 / 2$ & 1 & 2 \\
Supplier C & $1 / 2$ & 2 & 1 & 2 & 3 \\
Supplier D & $1 / 2$ & 1 & $1 / 2$ & 1 & 2 \\
Supplier E & $1 / 4$ & $1 / 2$ & $1 / 3$ & $1 / 2$ & 1 \\
\hline Total & $24 / 7$ & $71 / 2$ & $41 / 3$ & $61 / 2$ & 12
\end{tabular}

(Source: The researchers, 2017)
In Table 14, it can be seen that for consistent quality, Supplier A are 3 times better than Supplier B. Meanwhile, Supplier B is $1 / 3$ times better than Supplier A. Table 15 shows that in the frequency of defective products, Supplier A is 4 times better than Supplier B. However, Supplier B is 1/4 times better than Supplier A. From the result in Table 16, it can be analyzed that for speed of response, Supplier A is 2 times better than Supplier B. Then, Supplier B is $1 / 2$ times better than Supplier A.

Table 15 Paired Comparison Matrices among Suppliers based on Sub-Criteria of The Frequency of Defective Products

\begin{tabular}{cccccc}
\hline Pro3 & A & B & C & D & E \\
\hline Supplier A & 1 & 4 & 2 & 2 & 4 \\
Supplier B & $1 / 4$ & 1 & $1 / 2$ & 1 & 2 \\
Supplier C & $1 / 2$ & 2 & 1 & 4 & 4 \\
Supplier D & $1 / 2$ & 1 & $1 / 4$ & 1 & 2 \\
Supplier E & $1 / 4$ & $1 / 2$ & $1 / 4$ & $1 / 2$ & 1 \\
\hline Total & $21 / 2$ & $81 / 2$ & 4 & $81 / 2$ & 13 \\
\hline
\end{tabular}

(Source: The researchers, 2017)

Table 16 Paired Comparison Matrices among Suppliers based on Sub-Criteria of Speed of Response

\begin{tabular}{cccccc}
\hline Ser1 & A & B & C & D & E \\
\hline Supplier A & 1 & 2 & 1 & 2 & 2 \\
Supplier B & $1 / 2$ & 1 & $1 / 2$ & 1 & 2 \\
Supplier C & 1 & 2 & 1 & 2 & 2 \\
Supplier D & $1 / 2$ & 1 & $1 / 2$ & 1 & 1 \\
Supplier E & $1 / 2$ & $1 / 2$ & $1 / 2$ & 1 & 1 \\
\hline Total & $31 / 2$ & $61 / 2$ & $31 / 2$ & 7 & 8 \\
\hline
\end{tabular}

(Source: The researchers, 2017)

Table 17 Paired Comparison Matrices among Suppliers based on Sub-Criteria of After-Sales Warranty

\begin{tabular}{cccccc}
\hline Ser2 & A & B & C & D & E \\
\hline Supplier A & 1 & 2 & 1 & 2 & 2 \\
Supplier B & $1 / 2$ & 1 & 1 & 1 & 2 \\
Supplier C & 1 & 1 & 1 & 2 & 2 \\
Supplier D & $1 / 2$ & 1 & $1 / 2$ & 1 & 1 \\
Supplier E & $1 / 2$ & $1 / 2$ & $1 / 2$ & 1 & 1 \\
\hline Total & $31 / 2$ & $51 / 2$ & 4 & 7 & 8 \\
\hline
\end{tabular}

(Source: The researchers, 2017) 
From the result in Table 17, it can be seen that for after-sales warranty, Supplier A is 2 times better than Supplier B. Meanwhile, Supplier B is $1 / 2$ times better than Supplier A. In Table 18, for flexibility, Supplier A is 3 times better than Supplier B. However, Supplier B is $1 / 3$ times better than Supplier A.

Table 18 Paired Comparison Matrices among Suppliers based on Sub-Criteria of Flexibility

\begin{tabular}{cccccc}
\hline Ser3 & A & B & C & D & E \\
\hline Supplier A & 1 & 3 & 2 & 3 & 2 \\
Supplier B & $1 / 3$ & 1 & $1 / 2$ & 2 & 1 \\
Supplier C & $1 / 2$ & 2 & 1 & 1 & 2 \\
Supplier D & $1 / 3$ & $1 / 2$ & 1 & 1 & 1 \\
Supplier E & $1 / 2$ & 1 & $1 / 2$ & 1 & 1 \\
\hline Total & $22 / 3$ & $71 / 2$ & 5 & 8 & 7 \\
\hline
\end{tabular}

(Source: The researchers, 2017)

Table 19 Paired Comparison Matrices among Suppliers based on Sub-Criteria of Delivery Time

\begin{tabular}{cccccc}
\hline Del1 & A & B & C & D & E \\
\hline Supplier A & 1 & $1 / 2$ & 1 & $1 / 2$ & 1 \\
Supplier B & 2 & 1 & 2 & 2 & 3 \\
Supplier C & 1 & $1 / 2$ & 1 & 1 & 2 \\
Supplier D & 2 & $1 / 2$ & 1 & 1 & 2 \\
Supplier E & 1 & $1 / 3$ & $1 / 2$ & $1 / 2$ & 1 \\
\hline Total & 7 & $25 / 6$ & $51 / 2$ & 5 & 9 \\
\hline
\end{tabular}

(Source: The researchers, 2017)

In Table 19, for delivery time, Supplier A is $1 / 2$ times better than Supplier B. Then, Supplier B is 2 times better than Supplier A. From the result in Table 20 , it can be seen that for delivery cost, Supplier A are $1 / 3$ times better than Supplier B. However, Supplier B is 3 times better than Supplier A.

Table 20 Paired Comparison Matrices among Suppliers based on Sub-Criteria of Delivery Cost

\begin{tabular}{cccccc}
\hline Del2 & A & B & C & D & E \\
\hline Supplier A & 1 & $1 / 3$ & 1 & $1 / 3$ & 1 \\
Supplier B & 3 & 1 & 3 & 3 & 4 \\
Supplier C & 1 & $1 / 3$ & 1 & 1 & 1 \\
Supplier D & 3 & $1 / 3$ & 1 & 1 & 2 \\
Supplier E & 1 & $1 / 4$ & 1 & $1 / 2$ & 1 \\
\hline Total & 9 & $21 / 4$ & 7 & $55 / 6$ & 9
\end{tabular}

(Source: The researchers, 2017)
The objective of paired comparison data is to find out which supplier is best for Timber Industry for every criteria and sub-criteria. The inputs of Table 11 to Table 20 are used to calculate the weighted matrix of paired comparison in both criteria and sub-criteria. In this research, data processing is assisted by Expert Choice 11. For AHP analysis using Expert Choice 11 program, the criteria are shown in Table 21.

Table 21 Weighted Matrix of Paired Comparison for Criteria

\begin{tabular}{|c|c|}
\hline Criteria & Weighted Score \\
\hline Price & 0,350 \\
\hline Product & 0,322 \\
\hline Service & 0,112 \\
\hline Delivery & 0,216 \\
\hline Total & 1,000 \\
\hline Inconsistency & 0,04 \\
\hline
\end{tabular}

(Source: The researchers, 2017)

Based on Table 21, it can be analyzed that price is the best-prioritized criterion used in the selection of the best suppliers by Timber Industry. It is with a weighted value of 0,350 . The second best criterion is the product. It has a weighted value of 0,322 . Next, the third and fourth criteria are delivery and service with a weighted value of 0,216 and 0,112 respectively. The inconsistent value of respondents in filling of this criterion questionnaire is 0,04 or $4 \%$. The number is considered consistent because it is below the tolerance value of $10 \%$. The next step is to repeat the same steps for the sub-criteria category as well as the comparison between the entire suppliers.

Based on the outputs in Table 22, it can be seen that competitive price is the best sub-criteria of the price used in supplier selection by Timber Industry. It has a weighted value of 0,800 . Meanwhile, the consistent price has a weighted value of 0,200 . The inconsistent value of respondents in filling of subcriterion questionnaire is 0,00 or $0 \%$. It is considered as consistent because it is below the tolerance value of $10 \%$.

Table 22 Weighted Matrix of Paired Comparison for Sub-Criteria of Price

\begin{tabular}{cc}
\hline Sub-Criteria & Weighted Score \\
\hline Competitive price & 0,800 \\
Consistent price & 0,200 \\
\hline \multicolumn{1}{c}{ Total } & 1,000 \\
\hline Inconsistency & 0,000 \\
\hline
\end{tabular}

(Source: The researchers, 2017) 
Based on the outputs in Table 22, it can be seen that competitive price is the best sub-criteria of the price used in supplier selection by Timber Industry. It has a weighted value of 0,800 . Meanwhile, the consistent price has a weighted value of 0,200 . The inconsistent value of respondents in filling of subcriterion questionnaire is 0,00 or $0 \%$. It is considered to be consistent because it is below the tolerance value of $10 \%$.

Table 23 Weighted Matrix of Paired Comparison for Sub-Criteria of Product

\begin{tabular}{lc}
\hline Sub-Criteria & Weighted Score \\
\hline Availability of goods & 0,528 \\
Consistent quality & 0,140 \\
The frequency of defective & 0,333 \\
products & \\
\hline \multicolumn{1}{c}{ Total } & 1,000 \\
\hline \multicolumn{1}{c}{ Inconsistency } & 0,050 \\
\hline
\end{tabular}

(Source: The researchers, 2017)

In Table 23, it shows that the availability of goods is the best sub-criteria of the product. It is with a weighted value of 0,528 . It is followed by the frequency of defective products with a weighted value of 0,333 . Moreover, consistent quality, in this case, becomes the last sub-criterion of product. It has the lowest weighted value score of 0,140 . Then, the inconsistent value of respondents in filling of this sub-criterion questionnaire is 0,050 or $5 \%$, which is consistent because it is below the tolerance value of $10 \%$.

As seen in Table 24, after-sales warranty is the best sub-criterion of the service with a weighted value of 0,637 . Next, there is flexibility with a weighted value of 0,258 . The speed of response becomes the last sub-criterion of service because it has the lowest weighted value score of 0,105 . The inconsistent value in this sub-criterion is 0,040 or $4 \%$. The number is seen as consistent because it is below the tolerance value of $10 \%$.

Table 24 Weighted Matrix of Paired Comparison for Sub-Criteria of Service

\begin{tabular}{|c|c|}
\hline Sub-Criteria & Weighted Score \\
\hline Speed of response & 0,105 \\
\hline After-sales warranty & 0,637 \\
\hline Flexibility & 0,258 \\
\hline Total & 1,000 \\
\hline Inconsistency & 0,040 \\
\hline
\end{tabular}

(Source: The researchers, 2017)
Table 25 Weighted Matrix of Paired Comparison for Sub-Criteria of Delivery

\begin{tabular}{cc}
\hline Sub-Criteria & Weighted Score \\
\hline Delivery time & 0,167 \\
Delivery cost & 0,833 \\
\hline Total & 1,000 \\
\hline Inconsistency & 0,000 \\
\hline
\end{tabular}

(Source: The researchers, 2017)

Based on Table 25, it shows that delivery cost is the best sub-criterion in the delivery with a weighted value of 0,833 . It is followed by delivery time with a weighted value of 0,167 . Then, the inconsistent value in this sub-criterion questionnaire is 0,00 or $0 \%$. It is already consistent. Next, the researchers calculate the weighted value for each supplier. It is in accordance with the sub-criteria that have been determined. The result is shown in Table 26 to Table 29.

Table 26 Weighted Value of Price

\begin{tabular}{lcc}
\hline \multirow{2}{*}{ Sub-Criteria } & \multicolumn{2}{c}{ Weighted Score } \\
\cline { 2 - 3 } & Competitive price & Consistent price \\
\hline Supplier A & 0,209 & 0,213 \\
Supplier B & 0,394 & 0,460 \\
Supplier C & 0,209 & 0,133 \\
Supplier D & 0,076 & 0,066 \\
Supplier E & 0,113 & 0,128 \\
\hline \multicolumn{1}{c}{ Total } & 1,000 & 1,000 \\
\hline Inconsistency & 0,070 & 0,020 \\
\hline
\end{tabular}

(Source: The researchers, 2017)

In Table 26, it can be observed that Supplier $\mathrm{B}$ is the best supplier for the competitive price and consistent price. It has the weighted value of 0,394 and 0,460. Meanwhile, Supplier D has the lowest weighted value in this sub-criteria. Based on this result, it can be said that Supplier B has the best price.

Table 27 Weighted Value of Product

\begin{tabular}{cccc}
\hline & \multicolumn{3}{c}{ Weighted Score } \\
\cline { 2 - 4 } Criteria & $\begin{array}{c}\text { Availability } \\
\text { of Goods }\end{array}$ & $\begin{array}{c}\text { Consistent } \\
\text { Quality }\end{array}$ & $\begin{array}{c}\text { The Frequency } \\
\text { of Defective } \\
\text { Products }\end{array}$ \\
\hline Supplier A & 0,466 & 0,380 & 0,386 \\
Supplier B & 0,075 & 0,139 & 0,122 \\
Supplier C & 0,160 & 0,250 & 0,294 \\
Supplier D & 0,240 & 0,152 & 0,127 \\
Supplier E & 0,058 & 0,080 & 0,071 \\
\hline Total & 1,000 & 1,000 & 1,000 \\
\hline Inconsistency & 0,030 & 0,010 & 0,040 \\
\hline
\end{tabular}

(Source: The researchers, 2017) 
From Table 27, Supplier A is the best supplier for all sub-criteria of product. It has a weighted value of 0,466 for availability of goods, 0,380 for consistent quality, and 0,386 for the frequency of defective products. Different from the previous result, Supplier $\mathrm{E}$ has the lowest score in this criteria.

Table 28 Weighted Value of Service

\begin{tabular}{lccc}
\hline \multirow{2}{*}{$\begin{array}{c}\text { Sub- } \\
\text { Criteria }\end{array}$} & \multicolumn{3}{c}{ Weighted Score } \\
\cline { 2 - 4 } & $\begin{array}{c}\text { Speed of } \\
\text { Response }\end{array}$ & $\begin{array}{c}\text { After-Sales } \\
\text { Warranty }\end{array}$ & Flexibility \\
\hline Supplier A & 0,283 & 0,288 & 0,369 \\
Supplier B & 0,166 & 0,193 & 0,150 \\
Supplier C & 0,283 & 0,250 & 0,213 \\
Supplier D & 0,142 & 0,144 & 0,131 \\
Supplier E & 0,125 & 0,125 & 0,137 \\
\hline Total & 1,000 & 1,000 & 1,000 \\
\hline Inconsistency & 0,010 & 0,020 & 0,040 \\
\hline
\end{tabular}

(Source: The researchers, 2017)

Similarly, Supplier A is the best supplier for all sub-criteria of service in Table 28. It is with a weighted value of 0,283 for speed of response, 0,288 for aftersales warranty, and 0,369 for flexibility. Meanwhile, Supplier E scores the lowest in both speed of response and after-sales warranty with 0,125 . However, the lowest value in flexibility is by Supplier D.

From the output results in Table 29, it shows that Supplier B is the best supplier for delivery time and delivery cost. It has a weighted value of 0,348 and 0,436 for the sub-criterion. Similar to the previous result, in delivery, Supplier E has the lowest value in both sub-criteria.

Figure 2 shows the summary of the performance of the five suppliers based on the four predefined criteria. It can be seen that Supplier A has the best value in service and product. However, in price and delivery, Supplier B has the best value. Then, Supplier $\mathrm{E}$ has the lowest value in all criteria except price.

Table 29 Weighted Value of Delivery

\begin{tabular}{lcc}
\hline \multirow{2}{*}{ Sub-Criteria } & \multicolumn{2}{c}{ Weighted Score } \\
\cline { 2 - 3 } & Delivery Time & $\begin{array}{c}\text { Delivery } \\
\text { Cost }\end{array}$ \\
\hline Supplier A & 0,142 & 0,112 \\
Supplier B & 0,348 & 0,436 \\
Supplier C & 0,185 & 0,138 \\
Supplier D & 0,213 & 0,203 \\
Supplier E & 0,112 & 0,111 \\
\hline \multicolumn{1}{c}{ Total } & 1,000 & 1,000 \\
\hline Inconsistency & 0,020 & 0,030 \\
\hline
\end{tabular}

(Source: The researchers, 2017)

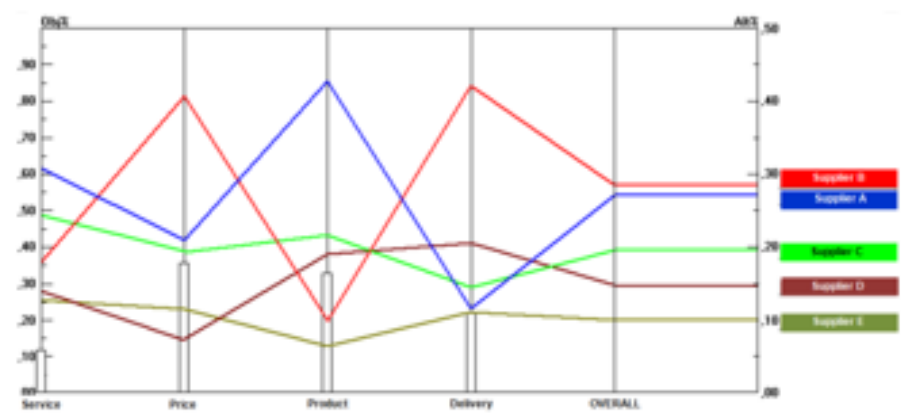

Figure 2 Supplier Performance Results

Table 30 Summary of Consistency Ratio (CR)

\begin{tabular}{cccc}
\hline Sub-Criteria & CR & $\begin{array}{c}\text { Tolerant } \\
\text { Limit }\end{array}$ & Result \\
\hline Pri1 & 0,07 & 0,1000 & Consistent \\
Pri2 & 0,02 & 0,1000 & Consistent \\
Pro1 & 0,03 & 0,1000 & Consistent \\
Pro2 & 0,01 & 0,1000 & Consistent \\
Pro3 & 0,04 & 0,1000 & Consistent \\
Ser1 & 0,01 & 0,1000 & Consistent \\
Ser2 & 0,02 & 0,1000 & Consistent \\
Ser3 & 0,04 & 0,1000 & Consistent \\
Del1 & 0,02 & 0,1000 & Consistent \\
Del2 & 0,03 & 0,1000 & Consistent \\
\hline
\end{tabular}

(Source: The researchers, 2017)

The inconsistency AHP model that uses human perception as its input, may occur. It is because humans have limitations in expressing their perceptions consistently, especially if they have to compare many criteria. The purpose of Consistency Ratio (CR) is to find out whether the data obtained is feasible and can be used and applied. If the test results obtained are inconsistent, the process will be performed from the initial step. AHP measures the overall consistency of various considerations through $\mathrm{CR}$, If the $\mathrm{CR}$ value is less than or equal to $0,1(\mathrm{CR}<=0,1)$, the consistency ratio is consistent and acceptable. However, if the CR is greater than $0,1(\mathrm{CR}>0,1)$, the consistency ratio is inconsistent (Khairina, 2012). From the calculation of Consistency Ratio (CR), the results can be summarized as shown in Table 30.

The output of overall weighting result becomes the basis for determining the best supplier for Timber Industry. The evaluation of the best supplier for Timber Industry using Expert Choice 11 can be seen in Figure 3. 


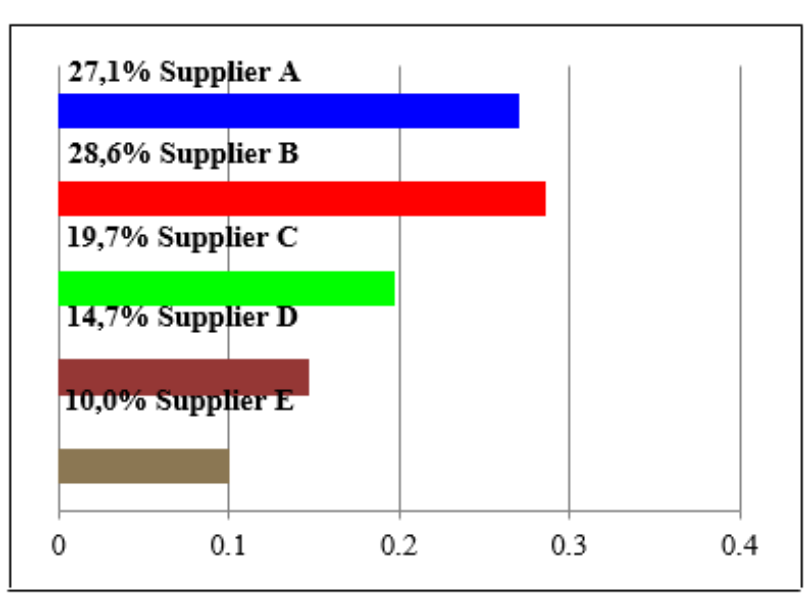

Figure 3 Result of Best Supplier Evaluation (Source: The researchers, 2017)

In Figure 3, the best supplier with AHP using Expert Choice 11 program is Supplier B. It has the value of $28,6 \%$. It implies that Supplier B is the best supplier for Timber Industry based on the predetermined criteria. The second best supplier is Supplier A with a value of $27,1 \%$. Then, it is followed by Suppliers C and Supplier D values of 19,7\% and $14,7 \%$. Supplier E is the least chosen with the value of $10,0 \%$.

For the first purpose (O1), the researchers find that the most prioritized criterion with the highest value is price with $35,0 \%$. It is followed by the product $(32,2 \%)$. The rest is delivery and service with $21,6 \%$ and $11,2 \%$ respectively.

From the AHP analysis, the researchers also determine the best supplier for Timber Industry in fulfilling its raw material needs $(\mathrm{O} 2)$. The most suitable supplier for timber industry is Supplier B (Awi Kayu). It has the highest weighted score $(28,6 \%)$. The second best supplier is Supplier A (Cahaya Abdi Karya) with a weighted score of 27,1\%. Then, the third best supplier is Supplier C (Mandiri Palet) with a weighted score of 19,7\%. The others, Supplier D (Aming Wood) and Supplier E (Abdi Karya) become the fourth and fifth supplier. Each weighted score is $14,7 \%$ and $10,0 \%$. The result obtained from this research is in line with the results of the other research. It explained the use of AHP technique to select the best supplier for a company decision-making process. Furthermore, it would reduce the level of subjectivity in supplier evaluation and selection and allow one to reach an optimal selection decision (Garoma and Diriba, 2014).

Based on the analysis, Timber Industry should establish long-term cooperation with Supplier B (Awi Kayu) and Supplier A (Cahaya Abdi Karya). The weighted score in AHP analysis of both suppliers is the best among other suppliers. If the company wants to develop the supplier capabilities, Supplier B (Awi Kayu) and Supplier A (Cahaya Abdi Karya) can be the choice for the company to invest in supplier development.

Furthermore, Timber Industry should continue to evaluate its suppliers periodically. It is because the quality of each supplier can change in the future, even though the current suppliers, Awi Kayu and Cahaya Abdi Karya, are the best supplier. This is intended to have suppliers which can meet the company's demand from time to time. The company should also evaluate criteria to select suppliers and observe whether there is a change in the criteria that the company needs.

\section{CONCLUSIONS}

From the results of the analysis, there are several conclusions. First, from the interview, the researchers obtain four criteria. Those criteria have several subcriteria. In price, there are competitive price and consistent price. For product, there are the availability of goods, consistent quality, and the frequency of defective products. Then, service consists of the speed of response, after-sales warranty, and flexibility. In delivery, there are delivery time and shipping cost.

Second, the researchers find out that the most prioritized criterion is price with the value of $35,0 \%$. Meanwhile, the lowest criterion is service with a value of $11,2 \%$. Third, the researchers agree that the best suppliers are Supplier B (Awi Kayu) and Supplier A (Cahaya Abdi Karya). Timber Industry should establish long-term cooperation with these suppliers.

By considering the complexity of the problem in supplier selection, AHP can be considered as an ideal tool. AHP can become an effective tool to optimize strategy undertaken by the company in evaluating company performance. Furthermore, the researchers suggest the company to evaluate the other needs required from each supplier periodically, so it can make the supplier's assessment become more comprehensive and up to date. Then, it is evident that different industry needs certain criteria and different importance level from each criterion.

Regarding the use of AHP in this research, once the criteria are identified, the selection the right supplier will be more convincing. So, the right criteria will be so important for research using AHP. Wrong criteria may mislead the company to make the wrong decision. Associated with that condition, the limitation of this research is the researchers have not yet compared the criteria from the other companies in the same industry and country. Thus, for future research, the researchers can do comparative study from several companies in the same industry to ensure the validity of criteria which is used. The research can compare the criteria and the importance level of each criterion from companies involved in the same industry. Then, the result can be used as a reference for the other companies in choosing criteria to select their suppliers easier, especially for them who are in the same industry.

\section{REFERENCES}

Ajami, S., \& Ketabi, S. (2012). Performance evaluation of medical records departments by Analytical Hierarchy Process (AHP) approach in the selected 
hospitals in Isfahan. Journal of Medical Systems, 36(3), 1165-1171.

Arama, M., Criste, V. I., Criste, R. D., \& Panaite, T. (2015). Use of multicriteria AHP (Analytical Hierarchy Process) method to rank feeding solutions, tested on layers, while observing environmental protection. Archiva Zootechnica, 18(2), 73-85.

Faisol, A., Muslim, M. A., \& Suyono, H. (2014). Komparasi Fuzzy AHP dengan AHP pada sistem pendukung keputusan investasi properti. Jurnal EECCIS, 8(2), 123-128.

Garoma, T., \& Diriba, S. (2014). Modeling and analysis of supplier selection method using Analytical Hierarchy Process (AHP). Science, Technology and Arts Research Journal, 3(1), 145-151.

Heizer, J., Render, B., \& Munson, C. (2016). Operations management: Sustainability and supply chain management. Harlow, England: Pearson.

Joshi, V., Lee, K., Melson, D., \& Narra, V. R. (2011). Empirical investigation of radiologists' priorities for PACS selection: An Analytical Hierarchy Process approach. Journal of Digital Imaging, 24(4), 700708.

Khairina, D. M. (2016). Analytical Hierarchy Process sebagai pendukung keputusan (decision support) pemilihan lokasi pembangunan rumah kos untuk karyawan. Informatika Mulawarman, 7(3), 75-81.

Marlinda, L. (2016). Sistem pendukung keputusan pemilihan tempat wisata yogyakarta menggunakan metode ELimination Et Choix Traduisant La RealitA (ELECTRE). In Prosiding Seminar Nasional Sains dan Teknologi.

Prasad, V. S., \& Kousalya, P. (2017). Role of consistency in analytic hierarchy process-consistency improvement methods. Indian Journal of Science and Technology, 10(29), 1-5.

Schmidt, K., Aumann, I., Hollander, I., Damm, K., \& von der Schulenburg, J. M. G. (2015). Applying the Analytic Hierarchy Process in healthcare research: A systematic literature review and evaluation of reporting. BMC medical informatics and decision making, 15(1), 112.

Sekaran, U., \& Bougie, R. (2013). Research methods for business. Chichester: Willey.

Supraja, S., \& Kousalya, P. (2016). ELECTRE Method for the selection of best computer system. Indian Journal of Science and Technology, 9(39), 1-5.

Yücel, M. G., \& Görener, A. (2016). Decision making for company acquisition by ELECTRE method. International Journal of Supply Chain Management, 5(1), 75-83. 